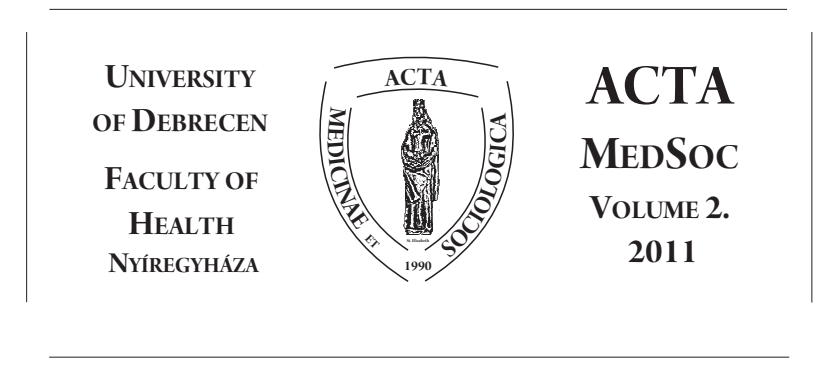

\title{
A posztadoleszcencia nyomában Végzôs hallgatók jövőképe az Egészségügyi Karon
}

\section{Oroszné Pál Zsuzsanna}

Debreceni Egyetem Egészségügyi Kar

\begin{abstract}
The issue of this study is about the future prospects of those students who studies in health faculty. We analyzed what they think about entering employement, proffessional challenges, marriage, having a baby and about their health.It is well known that it is not so easy for our youth. Nowadays one of the important challenges is the ambivalent characteristics of youth. They try to be more and more autonomous but the social, economical and cultural uncertainties make the self-realization difficult. That is why it is not so easy to become creative,selfconfident,emotionally steady and motivated. We delineate those factors which influence the development process of identity. Besides traditional mechanisms, the functions of consumer society and mass media are emphasized. We deal with emerging adulthood and ask them about these. Showing our results we can see their plains about their professions and being employed. Those experiences were predominated which are about the ambivalent factors of marriage and having a baby. Young people think it is difficult to find usefull freetime activities and if they have what can they do. Living a healthy life is also complicated for them. Using the results of the survey,we try to do our best to help young people finding a job in the supporting line.
\end{abstract}

Keywords: youth, future prospects, postadolescens identity, emerging adulthood, helping profession, health promotion

DOI: $10.19055 / \mathrm{ams} .2011 .2 / 2 / 4$ 
Lektor: Dr. habil Takács Ildikó, egyetemi docens, BME

\section{Bevezetés}

Jelen tanulmány témája a fiatalok jövóképe az egészségügyi karon. Azzal az életkorral foglalkozunk, amelyet a szakirodalom az életkor feladataival összhangban többek között emerging adulthood-nak (készülődő felnőttség) (ARNETT, 2007), posztadoleszcens-nek (KENISTON, 1970), „the boomerang age”-nek (MITCHELL, 2007) neveznek. Utalnak ezek az elnevezések arra, hogy a serdülő és felnôttkor között létezik egy átmeneti időszak, ami leginkább a felsőoktatásból kikerült fiatalokra jellemző. Ebben az időszakban nyit a fiatal a világra, keresi helyét, lehetôségeit az addigi zárt, megfelelő elvárásokat és védettséget jelentő tanulmányi évek után kikerülve az ismeretlen, felnôtt világba. Nagy próbatétel számukra, krízishelyzetként is értelmezhető, alkalmazkodni kell a bizonytalan emocionális, egzisztenciális létből származó nehézségekhez. A kapunyitási krízis jelensége ez, utalva ezzel az életciklus váltásból származó problémákra. (MAGYARI, 2009)

Kíváncsiságunkat elégítette ki ez a vizsgálat, mi szerint végzőseink, - akiket négy évig oktattunk a szakma elméleti és gyakorlati ismereteire, ezen kívül segítettünk olyan kompetenciák elsajátításában, amelyeket a mindennapi gyakorlatban alkalmazni tudnak, - hogyan vélekednek jövójükről, amikor az alma matert elhagyva, megkezdik önálló felnőtt életüket. Kíváncsiak voltunk hogyan vélekednek a munkavállalásról, szakmai kihívásokról, házasságról, gyermekvállalásról, egészségükról. Hogyan tudnak megbirkózni az életciklusból adódó kihívásokkal?

Mindenki számára ismert tény, hogy ez a feladat nem könnyú a fiataloknak. Az ifjúkor ambivalens jellemzői napjaink egyik fontos társadalmi kihívása. A fiatalok, úgy túnik, egyre önállóbbak próbálnak lenni, azonban a társadalmi, gazdasági, kulturális bizonytalanságok nehézzé teszik az önmegvalósítást. A pályakezdés és párválasztás bizonytalanságai mellett megjelenik egy értékválság, az eddigi norma és szabályrendszerek fellazulása, amely szintén problematikussá teszi az alkalmazkodást. Ebben a környezetben nehéz kreatív, magabiztos, stabil emocionális és motivációs jellemzókkel bíró fiatalnak lenni.

A társadalmi és gazdasági változások általi bizonytalanságok már nem teszik kiszámíthatóvá a jövôt, a fiataloknak sok mindenre fel kell készülniük, ez bizonyos mértékú félelmet kelt bennük. A mindennapokban beszélgetve hallgatóinkkal kitûnik, hogy érzik, és reális veszélyként élik meg az egzisztenciális és emocionális bizonytalanságot. Úgy gondolják, a felsőfokú végzettség már nem jelent egy garantált életszínvonalat és életpályát, csak egy irányvonalat ad. Felmerült bennünk a kérdés, vajon hogyan küzdenek meg ezekkel a nehézségekkel, milyen terveik vannak a bizonytalanságok kezelésében.

Hallgatóink segítő szakmában dolgoznak majd, segítő hivatást választottak, mely nem csak a klienssel kapcsolatban támaszt alapvetó követelményeket, hanem önmaguk számára is. Fontos, hogy önmagukat ismerô, a konfliktusokkal és nehézségekkel szembenézó, kompetens segítôk legyenek. Legyenek eszközeik, hogy 
megóvhassák testi, lelki egészségüket. A képzés során olyan készségeket kell elsajátítaniuk, amelyek segítségével hatékonyan megvalósíthatják ezt. Ez a vizsgálat kiindulópontja ennek a törekvésnek. Feltérképezzük azokat a jellegzetességeket, irányvonalakat, amelyek jellemzőek hallgatóinkra. A késóbbiekben pedig egy átfogó vizsgálat keretében azokat a készségeket, képességeket vizsgáljuk majd, amelyek segítenek a szakmai és személyes nehézségek megoldásában, a napi stressz kezelésében.

A rendszerváltás óta sok tanulmány foglalkozott a fiatalok életterv elképzeléseivel, jövőrôl vallott nézetei feltérképezésével. Mind a külföldi, mind a hazai szakirodalom megfogalmazza a posztadoleszcencia kifejezést, Somlai (2007) pedig „Új ifjúság”-nak nevezi ezt a korosztályt, akik életmódja, életlehetôségei eltérnek a korábbi standard életúthoz képest. Arnett (2007) „emerging adulthood”-nak nevezi ezt az időszakot, utalva a fejlődésre és a fejlődést akadályozó tényezók meglétére is. A Mitchell (2007) által leírt „the boomerang age” kifejezés is jelzi a korszak ambivalenciáját, az időnként önállósuló, majd újra a szülői házba visszatérô huszonévesek problémáját. Mielőtt rátérnék a vizsgálatunk ismertetésére, néhány gondolatban szeretném összefoglalni mi is jellemző erre a korosztályra, akikkel dolgozunk, akik számára lehetőséget adunk, hogy a serdülókori ambivalens létezés után kialakíthassák stabil identitásukat, nem csak a személyes élettérben, hanem a szakmai területeken is.

\section{Az identitás}

Az identitás kialakulása az ifjúkorra befejeződik. Az önmeghatározás aktív folyamatára Erikson bevezette az identitáskrízis kifejezést. Az identitáskrízis ideális esetben a húszas életévek elejére, közepére megoldódik. Az egyén akkor érte el identitását, ha elkötelezte magát egy nemi identitás, egy foglalkozás és egy ideológiai világnézet mellett. Az identitáskrízis megoldódása után rendelkezik az egyén konzisztens énképpel, és olyan belsô normákkal, amely alapján értékelheti magát az élet különbözô területein (ATKINSON és munkatársai, 2003).

Ahhoz, hogy az egyén ezt megvalósíthassa, három fontos feladatot kell megoldania:

1. el kell vállalnia a felnôtt ember társadalmi szerepét, beleértve az önálló életvitelt, a megfelelő pálya megválasztását, a saját sorsáért - sôt, mások sorsáért - érzett felelôsséget is,

2. képessé kell válnia arra, hogy magának társat, érzelmeinek tárgyat a családon kívül találjon,

3. szexuális fejlődésében el kell érnie azt a fokot, amikor a kielégülés legfóbb forrása a másnemú partnerrel történő nemi együttlét (VIKÁR, 1999).

Arnett (2000) szerint a felnőttségnek három kritériuma van: 
1. Saját magáért való felelősség vállalása.

2. Önálló döntések meghozatalára való képesség.

3. Anyagi függetlenség biztosítása.

Ez a folyamat napjainkban változásokon megy keresztül. Az identitás kialakításában szerepet játszó hagyományos elemeken (család, iskola, kortársak) kívül új, nagy jelentőséggel bíró tényezôk is szerepet kapnak. A fogyasztói társadalom modellje, mint értékformáló eszköz az egyéni érdekek, motivációk szerepét hangsúlyozzák, ugyanakkor uniformizálnak is, amely az individualizáció folyamatában negatív befolyással bír. A vallásosság, mely szintén megjelenő értékformáló tényezô, a realitás keretein belül védőfaktorként is megjelenik a kockázatos magatartások terén. A vallással kapcsolatban álló fiatalok körében kevesebb az alkohol, drogfogyasztás, dohányzás (PIKÓ, 2005). Harmadik fontos identitásformáló tényezô napjaink információs társadalma. Míg korábban a fiatalok összejövetelekre jártak, manapság internet, mobiltelefon jelenti a kapcsolatot. Az innen származó információk lényegesen megváltoztatták az önmagukról, mint közösségi emberról, önmagukról, mint individuumról vallott nézeteket. Ezeken kívül a gyorsuló idô, az idókényszer, a közösségi értékek háttérbe szorulása, átalakulása tovább nehezíti az identitáskialakítás folyamatát. Éppen ezért, az identitás nehezen kialakítható, nem egyértelmúen a hagyományos értékrendek alapján alakul, hanem egyéni, családi koncepciók, életszakaszok sokféleségéből alakul ki.

Az identitás egyik fontos összetevôje az ,állás”, a keresô munka, és a stabil alkalmazással járó jövedelem. A standard munkaviszony felbomlásából származó bizonytalanság hozzájárul ahhoz, hogy a fiatalok keresik identitásukat (SOMLAI, 2007). A szakma a többségnek már nem határozza meg identitását, viszont az életpálya az ember személyiségét, személyes és társadalmi identitását is átformálja (SOMLAI, 2007).

Az identitás másik fontos összetevője a párválasztás, a stabil emocionális kapcsolat kialakítása ellenkező nemú partnerrel. Ennek megvalósítása fontos a késóbbi élethelyzetek megoldásában, valamint abban, hogy az egyén alkotó, teremtő igényeit, késztetéseit megvalósíthassa, ezzel is erôsítve identitását.

Erikson szerint a serdülókori identitáskeresés befejeztével az egyén átlép az intimitás iránti igény az izolációval szemben időszakába. Az intimitás meghitt kapcsolat valakivel, amely magában foglalja az illető iránti elkötelezettséget. Az elkötelezettség vállalása nem csupán a párválasztásra vonatkozik. Az egyénnek képesnek kell lennie erre az élet más területein is. A tapasztalatok azt mutatják, hogy az átlépés ebbe a szakaszba nem zökkenőmentes napjaink társadalmi valóságában. Olyan társadalmi és kulturális változások következtek be, amelyek átformálták az életterveket, amelyek eredményeképpen megváltozott a standard életút modell. És ennek következtében az izoláció, az elmagányosodás, egzisztenciális bizonytalanság, az inkompetencia érzése erôsödik. Erre az instabilitásra válasz a kapunyitási krízis. Ebben az időszakban a fiatalok egy része folyamatosan megkérdőjelezi önmagát, elveszti stabil identitás érzését. Bizonytalanná válik a pályaválasztás, 
párválasztás, családalapítás. Sokan a depresszió jeleit mutatják. Margitics (2006) vizsgálatába a fóiskolai hallgatók esetén a szubklinikus depresszió fokozott jelenlétét találta, melynek okai között a belsô kontroll, az egyéni életvezetési készségek hiányát is látta. A krízis megoldásának lehetôségei széles körúek, Lukács (2007) a fiatal pályaidentitásának mértékét, a személyiségtípust, Makai (2005) a meglévő munkatapasztalatot, vagy annak hiányát, a fiatal nemét, a szülók iskolai végzettségét hangsúlyozza. Ezen kívül a családi dinamika nyomán kialakuló pszichológiai jellemzók is befolyásolják a krízis kimenetelét (MAGYAR, 2009)

\section{Posztadoleszcencia jelensége}

Keniston 1960-ban bevezette a posztadoleszcensek kifejezést a kialakult új ifjúság megnevezésére (SOMLAI, 2007). Ôk azok, akik még általában tanulnak, önálló keresettel nem rendelkeznek, a szüleikkel élnek, saját családjuk nincs, és élvezik gondtalan fiatal életüket. Ezek a fiatalok a húszas éveik elején járó, önálló életvitellel nem rendelkeznek. Szüleik támogatására szorulnak mind egzisztenciális, mind emocionális téren. Kevésbé önállóak, ami megnehezíti az alkalmazkodást és az önálló élet kialakítását.

Ez a jelenség napjainkban egyre általánossá válik. Az iskolarendszer expanziója, hogy a fiatalok nagy része továbbtanul, a tanulmányi idô meghosszabbodik. A keresố tevékenység is késôbb indul, aminek következménye a késóbbi párválasztás és családalapítás, gyermekvállalás. Az önálló élet kialakításának elhúzódása vezethet önértékelési és identitásbeli bizonytalanságokhoz.

Ismert demográfiai mutatók is jelzik ezeket a változásokat. Tovább bonyolítja a helyzetet a megváltozott párkapcsolati minták megjelenése, mint az élettársi kapcsolat, házasságon kívüli gyermekvállalás. Ugyanakkor nố a válások száma, csökken a házasodási és gyermekvállalási kedv, későbbi életkorban vállalnak a nôk gyermeket. A mai fiatalok a családon kívül elérhetô karrierre szocializálódnak, úgy gondolják, hogy ebben a gyermekvállalás csak akadályozza óket. A vizsgálatok szerint az elsố gyermek születésének ideális idôpontja nôknél a 22. és a 27. életév között van, ezzel szemben ma sok nő csak a 30. életéve körül kezd el gyermekvállaláson gondolkodni. Régebben a nők 22-24 évesen vállalták elsố gyermeküket. Az apává válás ideális életszakasza a 28. és a 32. életév között van, mert a férfiaknál nem biológiai alapja van az apaságnak, hanem arra nevelni kell óket. A férfiaknál sokkal később jelentkezik a vágy a gyermek és a család után (RANSCHBURG, 2007b)

Az Ifjúság 2004. kutatásból kiderül, hogy az egyetemisták 21\%-a 3 vagy több gyermeket tervez, míg kortársaiknál ez az arány 13.8\%. A fóiskolásoknál 19.3\% ez az arány, míg a teljes fiatal populációnál 14.3\% (KABAI, 2007). Megjelenik a tudatos gyermektelenség jelensége is, amely komoly demográfiai, társadalmi és individuális problémákhoz vezethet.

A változások oka sokrétú. Napjaink társadalmi perspektívátlansága az egyik jelentős tényezô, amely mind az identitás kialakítására, mind az életút választására hatással van. Az egzisztenciális bizonytalanságok, a munkavállalás nehézségei, 
a pályakezdő diplomás munkanélküliek számának emelkedése okoz problémákat, teszi bizonytalanná a jövoot. Ezek a tényezôk a mi hallgatóink munkába állását is befolyásolják. A szakmák túltelítettek, a hallgatóink egy része, mint ahogy majd a vizsgálatban is látni fogjuk, bizonytalan a kereső tevékenység megválasztásában. A foglalkozási orientáció pszichológiai kérdés is, mivel úgy kell kiválasztania leendó munkáját, hogy személyi képességeinek legjobban megfeleljen. A megfelelően kialakult identitás segíti ebben.

A változásokat befolyásoló másik fontos tényezó az individualizáció túlhangsúlyozása napjainkban, a közösségi értékek csökkenése mellett. Ennek következtében a társas közeg védelmi ereje csökken, az egyén egyedül marad. Ez nehezíti a párkapcsolatok kialakítását, valamint olyan készségek elsajátítását, és alkalmazását, amelyek a felnôtt élet nélkülözhetetlen részei. Hazai és nemzetközi kutatások számolnak be a szociális kapcsolatok pozitív szerepéról többek között az egyéni integritás, az élettel való elégedettség, az egészségmagatartás kérdésköreiben. (PUSKÂSSUSÁNSZKY, 2010) A csoporthoz tartozás, a szolidaritás érzése a fiatal számára megkönnyíti a leválást a szülókről. Az érzelmi kapcsolatok egy speciális formáját jelentik az ifjú számára és biztonságérzetet adnak neki.

Az ismerkedés manapság nem könnyû a fiataloknak. A hagyományos nemi szerepekre nevelő családban felnövekedett fiatal nehezen találja fel magát a sokféle ismerkedési, kezdeményezési forma között (TÓTH, 2007). Az ismerkedés ma már kevésbé sztereotip, kevésbé mereven szabályozott, mint a szülők életében volt, de ez nem jelenti azt, hogy könnyebb, hiszen vannak fiatalok, akik nem tudnak élni ezzel a széles ismerkedési repertoárral.

Ma a fiataloknak az ismerkedési lehetőségek széles skálája adott. A fiatalok aktív életvitelük ellenére nem tudnak könnyebben kapcsolatokat létesíteni. A sokszínú szórakozási lehetôségek, a hosszabb tanulmányi idô, a munkalehetôségek éppen kötetlenségükkel gátolják a kapcsolatok kialakítását és növelik a fiatalok szorongását. A szülők nehezen értik meg, hogy a nagy társasági élet ellenére miért van gyermekük pár nélkül.

Az egyének egyre később választanak partnert, bár ez a tendencia a rendszerváltás körül elkezdődött. Csökken a 20 éves korukig tartós kapcsolatot létesítók száma. A tanulmányi idő meghosszabbodása kitolja a házasságkötés és a gyermekvállalás idejét (PONGRÁCZ, 2002). A házasság megkötésének átlagéletkora 20\%-kal emelkedett, és a házasságkötési arány 40\%-kal visszaesett (KAMARÁS, 2005). 2005-ben az elsố házasságkötés átlagos életkora férfiaknál 28.2 év, nơknél 25.7 év volt (TÓTH, 2007).

Az élettársi kapcsolat megszünteti a házasság kizárólagos voltát, sokan „próbaházasságként" vagy tartós együttélési formaként értelmezik. Új keletú jelenség az élettársi formában alapított elsô partnerkapcsolat, amely az elmúlt 15 év alatt dominánssá vált (SPÉDER, 2005). A felsőfokú végzettségűek körében is egyre nagyobb a partnerkapcsolati életpályájukat élettársi viszonnyal kezdók aránya (SPÉDER, 2005). Azonban sokan csak ,átmeneti” életformának tekintik az élettársi viszonyt. Egyre több élettársi kapcsolatból lesz házasság. A kutatások alapján 
azonban a közvetlenül házasságként induló párkapcsolatok tartósabbak.

A társadalmi rendszer, a világkép értékrendszerének változásai, válságai további nehézséget jelentenek. Nincsenek jól körülhatárolható, stabil szabályok, normák, ugyanakkor a társadalom túlszabályozottsága is érvényesül bizonyos területeken. Ez az ambivalencia is tovább nehezítheti az optimális társas kapcsolatok létesítését, az egyéni személyiségfejlődés jó ütemú megvalósítását, a jövő tervezését.

Ehhez stabil értékek, belső kontroll szükséges, mely kialakításában a család nélkülözhetetlen szerepe ismert. Ismert az a tény is, hogy a családok válságát éljük, a család modell értéke, mintakövetési struktúrákban betöltött szerepe veszített értékéból.

A család az a terep, ahol a fiatal a legmagabiztosabban és legnyugodtabban mozog, bár a szülókkel való kapcsolata sokszor konfliktusokkal terhes. A szülók, és gyermekük között pszichés gát jön létre, mert a gyermek önállósodna, a szülô pedig késleltetni szeretné a gyermek önállósodását.

A szülooktől való elköltözés érett személyiséget feltételez, és a leválás fontos mozzanata. Lehetnek előzményei, valamint végbemehet fokozatosan is. Sokáig a korai elköltözés volt jellemzô, manapság azonban sok olyan fiatal is otthon lakik, aki már megszerezte diplomáját, és megbízható munkával rendelkezik. A meghosszabbodó kamaszkor jellegzetessége a hazaköltözés. Mitchell (2007) „,boomerang age”-nek nevezi ezt az idôszakot, éppen arra utalva ezzel, hogy nincs önálló egzisztencia, a szülooi ház állandóan rendelkezésre áll. Az elköltözés motívumait, idôzítését és a leválás folyamatát megváltoztatta a bizonytalanság (SOMLAI, 2007).

Az elköltözés Magyarországon a házasságkötéshez, újabban az élettársi kapcsolat létesítéséhez, és a gyermekvállaláshoz kötődik (BOGNÁR, 2007). Az elköltözéshez saját lakás szükséges, amelyhez sok fiatalnak nincs forrása.

A család másrészrôl nem biztosít az egyénnek olyan biztonságos emocionális légkört, amelyben önmaga lehet, amelyben vállalhatja hibáit és tanulhat ezekból, a család oltalmazó visszajelzései segítségével. Fontos ez a terep, fontos a belsô önálló gondolkodás, értékrend kialakításához és a megfelelő kontrollfunkciók múködtetéséhez. Hiszen csak azok a fiatalok bíznak a jövóben, tudják alakítani biztonsággal életüket, és ez az élet örömmel és kompetenciaérzéssel tölti el ooket, akik tudják irányítani saját belsố folyamataikat, ismerik önmagukat.

Magyari Judit (2009) tanulmányában a családi rendszer mentén kialakuló selfdifferenciáció minôségét hangsúlyozza a pályaképpel, jövôképpel való félelmek, szorongások kezelésében. Azok az egyének, akik képesek autonóm módon funkcionálni, nincsenek érzelmi függôségben másokkal, de aktív, kompetens kötôdést tudnak megvalósítani, tehát a self differenciáció magas szintjét mutatják, pozitívabb pályaképpel, magasabb énhatékonysággal jellemezhetók. 
Ennek a folyamatnak a megvalósítása elengedhetetlen a segítő szakmákban dolgozóknál. Stabil, kiegyensúlyozott személyiséggel, önálló felnótt léttel kell rendelkezni, hogy segíteni tudjon és önmagát is megvédje, egészségét megôrizze.

A fent felsorolt tényezók, melyek szerepet játszanak az elhúzódó kamaszkor mögött, jelentősen befolyásolják és nehezítik hallgatóink felnôtté válását, életút terveit.

Mind a pályaválasztás, mind a munkába állás területein tapasztalunk bizonytalanságokat a hallgatók által, a mindennapokban megfogalmazott véleményükben. Nem igazán motiváltak a szakma végzésére, már a szakválasztásnál sem a hivatástudat irányította ôket. Nem látják a lehetőségeket a munkavállalásnál, nem tudják, hol helyezkedhetnének el.

A beszélgetések során tapasztaljuk, és a közösségi programok alulszervezettségén látjuk a társas kapcsolatok kialakításának nehézségeit, a közösségi értékek hiányát. A közös programok, az együttlét tartalmas eltöltése nem érték. Ezzel szemben a fogyasztói ideálok, a tömegkommunikáció hatásai érvényesülnek. Tapasztalatunk, hogy az egészség megörzése sem jelent preferenciát a hallgatóknál, egészségügyi kar lévén, ez sajátos paradoxon.

A párválasztás nehézségei is szóba kerülnek. A gyermekvállalás és házasság imént felvázolt anomáliái is befolyásolják életüket.

A familiáris problémák is megjelennek, a szocializációs hiányosságok, a családi pozitív emocionális légkör hiánya.

Ezekkel a nehézségekkel kell szembe nézniük hallgatóinknak. Kérdésünk, hogy ezek a tapasztalatok hogyan nyilvánulnak meg a végzősök körében, milyen mértékben jellemző körükben a posztadolescencia jelensége. Hogyan vélekednek arról, hogy ebben a nehéz társadalmi, gazdasági, emocionális és értékválsággal jellemezhetô realitásban, hogyan tervezik életüket, jövőjüket.

\section{A vizsgálat}

Mint ahogy az előzőekben jellemeztük, napjaink bizonytalan, gazdasági, társadalmi, szociális, emocionális problémákkal küzdő világában, nem könnyû jövôt tervezni, különösen friss diplomásként. Arra voltunk kíváncsiak, vajon mit gondolnak a jövőjükrôl, mit terveznek a végzős hallgatóink. Rákérdeztünk a pályaválasztásuk motivációjára, miért választották ezeket a szakokat, illetve ebben szeretnének-e majd dolgozni. Érdekelt, hogy rájuk is jellemzô-e a szakirodalmak által felvázolt tendencia: az élettársi kapcsolatok preferálása, a házasodási kedv csökkenése, a gyermekvállalás későbbi időzítése az életútban. Egészségmegôrzés és szabadidős tevékenységek preferenciáit is vizsgáltuk.

A vizsgálat kérdőívének elkészítését egy elôvizsgálat előzte meg, mely során az alábbi témákban kértük a hallgatók véleményét. Olyan nyitott kérdésekre vártuk a válaszokat, mint, milyen tényezốk befolyásolják szakmaválasztását, milyennek képzeli jövendő munkáját, milyenek a párválasztásra, családalapításra vonatkozó elképzelései, jövőbeli tervei. Arra is választ vártunk, milyenek az egészségmegör- 
zésre vonatkozó elképzeléseik, szabadidős preferenciáik.

Ezen kérdésekre kapott válaszok alapján készítettük el a kérdôívet, mely 13 kérdésból állt, melyek mindegyike alkérdéseket tartalmazott. A kérdőív Lickert típusú, 5 fokozatú skálán alapult. A kérdések az alábbi témakörök köré szerveződtek:

- a szakmaválasztás befolyásoló tényezôk,

- a munkavállalást befolyásoló tényezók,

- a párválasztás, házasság befolyásoló tényezôi,

- a gyermekvállalásra vonatkozó nézetek,

- a következő 10 év tervei,

- az egészségmegörzés,

- a szabadidô eltöltés jellemzôi.

Elvárásaink, hipotéziseink azon kívül, hogy megpróbáltunk képet kapni a végzősök jövôre vonatkozó terveire, az azt befolyásoló leggyakoribb tényezókre, a következók voltak:

- A pályaválasztásnál a hivatással összefüggô attitúdök kevésbé befolyásolnak

- A végzôseink a választott szak által képviselt munkaterületen kevésbé kívánnak elhelyezkedni. A munkavállalásnál egzisztenciális értékek jelennek meg.

- Párkapcsolati, házasodási terveik megegyeznek a szakirodalomban található tendenciákkal, miszerint késóbbi életkorban, nehezebb körülmények között választanak társat, valamint a házasság lehetôsége háttérbe szorul.

- Ezen posztadoleszcens jellegzetességek érvényesek a gyermekvállalásra is.

- Egészségük megốrzése fontos számukra,

- és a szabadidő kevésbé tartalmas eltöltésével találkozhatunk.

Demográfiai kérdéseket is tartalmazott kérdőívünk, a nemre, életkorra, lakóhelyre és a szülők iskolai végzettségére vonatkozóan.

A vizsgálat során tehát a Debreceni Egyetem Egészségügyi Karán tanuló, pályakezdés előtt álló nappali tagozatos fiatalokat kérdeztük meg kérdőíves módszerrel jövőképükrôl.

A kérdőívet 113 hallgató töltötte ki, akik közül 13 fiú és 100 lány volt. A nemek arányának eltolódása nem meglepő, hiszen karunkon folyó szakmai képzések "elnôiesedett" szakmákra vonatkozik. A megkérdezettek átlagéletkora 21 év.

A válaszolók között minden alapszak képviseltette magát a Karról, megoszlásuk a mellékelt 1 . ábra alapján. 


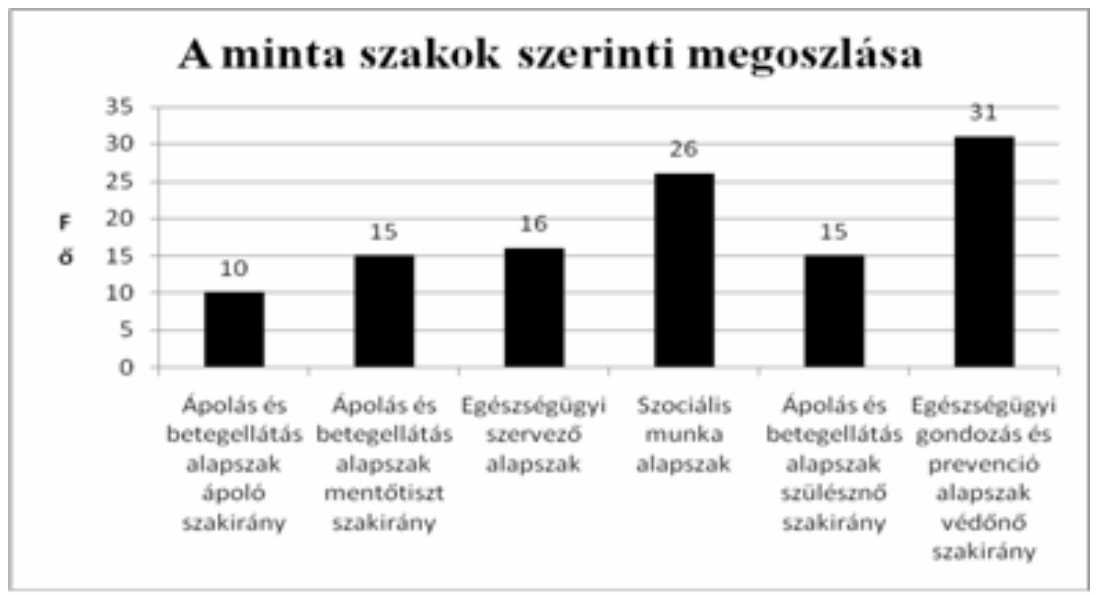

1. ábra. A minta szakok szerinti megoszlása

Lényegesnek tartottuk a hallgatók lakóhelyére vonatkozó adatainak és a szülők iskolai végzettségére vonatkozó adatok feltérképezését. Azért, mert e tényezók befolyásolják azokat a norma és szabályrendszereket, amelyek meghatározzák az egyén értékpreferenciáit, szocializációs folyamatait. Ezek a tényezők jelentôsen hozzájárulnak az egyéni életút kialakításához. Az alábbi táblázatok mutatják ezek megoszlását.

A hallgatók lakóhely szerinti megoszlása:

$\begin{array}{cc}\text { Fơváros, megyei jogú város } & 24 \% \\ \text { Kisebb város } & 38 \% \\ \text { Község, falu } & 38 \%\end{array}$

A hallgatók szüleinek iskolai végzettsége:

\begin{tabular}{ccc} 
Iskolai végzettség & Apa & Anya \\
\hline 8 általános & $4 \%$ & $10 \%$ \\
Szakmunkás & $51 \%$ & $22 \%$ \\
Érettségi & $30 \%$ & $45 \%$ \\
Felsófokú & $13 \%$ & $22 \%$
\end{tabular}

Az adatok statisztikai feldolgozása során (kereszttábla, khi négyzet próba segítségével) a minta kis száma eredményeképpen markáns szignifikáns eltérést nem találtunk a nem, a lakóhely és a szülők iskolai végzettsége tekintetében. Azonban tendenciákat, jellegzetességeket igen, melyek ellenôrzése nagyobb, átfogóbb kutatást igényelne. Azonban számunkra ezek a következókben ismertetésre kerülő eredmények jól hasznosíthatóak a mindennapi oktatási tevékenységben. 
A szakmaválasztást befolyásoló tényezôk közül a legjellegzetesebb a saját érdeklődési kör választása, valamint az emberekkel való foglalkozás vágya és a szakma jellege, kihívást, mozgalmasságot magába foglaló munka. A segítő szakma attitüdje nyilvánul itt meg, valamint érdekes módon nem kényszerválasztás, ahogy azt vártuk, hanem személyes bevonódás, önálló, külsô hatásoktól mentes választás. Fontos kérdés, és a továbbiakban vizsgálandó, hogy vajon ez az attitûd a tanulmányok kezdetétől jelen van, vagy a képzés során formálódott. Az elhelyezkedési esélyek ismerete kevésbé fontos számukra. Ennek tudatosítása azonban alapvetô feladatunk, hiszen a végzéskor szembesülve a szúkös lehetőségekkel komoly krízishelyzetet, emocionális, szociális instabilitást eredményezhet.

A főiskola elvégzése után a megkérdezettek nagy része a szakmában való elhelyezkedést látja reálisnak. Amennyiben érvényes az a tendencia, hogy a szakmaválasztásnál is segítő attitúdök érvényesültek, a hallgatókról elmondható, hogy motiváltak és a képzés alatt csak megerősödött bennük a szakma iránti elkötelezettség, nem riadtak meg a rájuk váró kihívásoktól. Ami azt is jelentheti, hogy jól mérték fel a pályaválasztásnál a képességeiket és a képzés megerôsítette ôket a választásukban. Ez ellent mond tapasztalatainknak és elvárásainknak, miszerint a hallgatók elkötelezettebbek a választott szak iránt, mint gondoltuk.

A munkaválasztást befolyásoló tényezôk közül nem a karrier adta lehetóségeket preferálják hallgatóink, hanem az emocionális, szociális faktorok érvényesülnek. Legjobban a munkahely légköre, a kollégákkal való jó kapcsolat hozott domináns válaszokat.

A korra jellemzô eltávolodás a szülőktől markánsan jelenik meg a felmérésben. Kevesen választják azt a lehetôséget, hogy szülőhelyükre térnek vissza a végzés után. Egyrészt ebben mindenképpen látnunk kell a szúkös elhelyezkedési lehetőségeket, másrészt az életkor függetlenedési törekvéseit. Nagyobb városokban szeretnének érvényesülni.

A házasságkötés és gyermekvállalás a nók esetében dominánsabb tervként jelenik meg, mint férfi hallgatóinknál. Valamint e jövóbeni tervek az alacsonyabb iskolai végzettségú szülók gyermekeinél is dominánsabban van jelen. A nemi szerepek sajátosságait, valamint a szülói minta jellegzetességeit követhetjük itt nyomon.

Viszonylag nagyobb gyakorisággal választották a továbbtanulás, nyelvtanulás lehetôségét. A szakmában való szûkös elhelyezkedési lehetôségek miatt ez a választás tovább tolja az önálló élet megkezdésének idejét.

Az egyéb munka vállalása nem jellemző, a hallgatók nem szívesen, végeznek más tevékenységet, és reálisan látják, hogy nincs is lehetôségük erre.

A külföldre költözést sem tervezik a fiatalok, talán bátortalanok, nem mernek nekivágni az ismeretlennek.

A párválasztás, házasságkötés témakörében a stabil munkahely megléte, az anyagi biztonság fontos a fiataloknak. Ezen kívül a párkapcsolat minôsége, és a pszichológiai érettség is megjelenik. Úgy túnik, reálisan, érzelmi és egzisztenciális tényezóket figyelembe véve, tudatosan döntenek ebben a kérdésben, tervezik a jövôt. 
A nóknek a párkapcsolat minősége fontosabb a házasságkötés szempontjából, mint a férfiaknak. Az anyagi háttér viszont a férfiaknál hangsúlyosabb, ami összefügghet a klasszikus nemi szerepekkel: a férfi a családfenntartó, a férfi akkor házasodik, ha tudja ezt a szerepet vállalni.

Tendenciaként megjelenik, hogy az apa legmagasabb iskolai végzettségének emelkedésével a karrier egyre nagyobb szerepet kap a házasságot befolyásoló tényezők között. A családban az apa norma- illetve értékközvetítő funkciói, a racionális dolgokhoz való viszonyulása jelenik itt meg, az értékek, értékpreferenciák családból hozott mintázatainak eltérése. Xiao és Andes (1999) kutatásai is kiemelik az apák konformitást, tekintélyt fontosnak tartó nevelési preferenciáit, szemben az anyák emocionális, boldogulásért, boldogságért felelôs nevelési attitűdjeikkel.

A gyermekvállalási kedv részben tükrözi a szakirodalmi adatokat (2. ábra). Míg Kabai (2007) kutatásában az a tendencia érvényesül, hogy a felsőoktatásban tanulók nagyobb százaléka vállalna 3, vagy több gyermeket az átlagos népességhez képest, itt azt látjuk, hogy az átlagos tervezett gyerekszám 2, (a fiúknál az átlag 1.92 lett, a lányoknál 2.18). Mindannyiunk számára elgondolkodtató tény, hogy egészséges, leendő értelmiségi fiatalok nem mernek több gyermeket vállalni. Bár ennek oka sokrétú. A társadalomban érzékelhetô bizonytalanság, a jövô kiszámíthatatlansága, az a tudat, hogy leendô szakmájuk nem feltétlenül biztosít megfeleló egzisztenciát, a családi értékek, normák válsága bizalmatlanná, bizonytalanná teszi a fiatalokat. Ha igazán bíznak a jövóben és az óket körülvevô társadalmi, kulturális világban, valószínúleg több gyermeket terveznének. A 8 általános iskolai végzettséggel rendelkezô szülők gyermekei inkább közelítenek a 3 tervezett gyermekszám felé. Érdekes tendencia, talán itt jobban érvényesülnek a régebbi társadalmi elvárások, hagyományok, valamint a standard életformára jellemzô cél, a gyermek felnevelése, a karrier háttérbe szorítása. Mindenestre az a tény, hogy így terveznek fiataljaink és tudjuk, hogy ezek tervek, amelyek sok esetben még kisebb valószínúséggel valósulnak meg, tovább nehezíti a helyzetet. Valamint megjelenik az a tendencia is, hogy nem kívánnak gyermeket vállalni, ami a szüloóvé, felnôtté válás folyamatának megváltozásához vezet, és ezen keresztül társadalmi és emocionális problémákhoz. A gyermekvállalást befolyásoló tényezók közül, mint ahogy azt a fenti grafikon mutatja, nagy szerephez jut a párkapcsolat minósége (4.6 átlag, az ötfokú skálán). Ezt az érzelmi háttér követi (4.53), valamint a stabil munkahely megléte (4.39)., a tanulmányok befejezése és az anyagi háttér hasonló mértékben befolyásolja a tényleges gyermekvállalást. Ahogy azt vártuk, a biológiai életkor és a házasságkötés a legkevésbé preferált tényezők. A bevezetôben ismertetett szakirodalmi adatok szerint egyre kevesebb gyermek születik házasságban, egyre többen élettársi kapcsolatban vállalnak gyermekeket, a kutatás eredményei is azt mutatják, hogy manapság már nem feltétele a családalapításnak a házasságkötés, bár azért sokan a gyermek szempontjából ideálisabbnak találják a házasságkötést. Azt viszont aggasztónak tartom, hogy a biológiai életkort nem veszik figyelembe, hisz az életkor előrehaladtával csökken a teherbeesés valószínúsége, és a magyarországi statisztikák a fiatal párok körében 30\%-ra teszik a funkcionális meddőség előfordu- 




2. ábra. A tényleges gyermekvállalási kedv a mintában.

lását. Erre mindenképpen fel kell hívni a figyelmüket.

A gyermekvállalás idôpontja is egyezik a szakirodalmi adatokkal. (RANSCHBURG, 2007b) A hallgatók 47\%-a a végzés után 5-7 éven belül tervezi , és csupán 25\%-a a végzés utáni három évben. 28\%-a pedig 7 éven túl, a huszas életéveik végén.

Az elkövetkezendő 10 évben a legfontosabb tényezők a hallgatók számára a következók (3. ábra). A táblázat értékei, az ötfokú skálán elért átlagos értékeket mutatják. A legfontosabb az egészség, ami egészségügyi kar lévén hangsúlyos és fontos a hallgatók életterveiben. A boldogság „második helyezése” a serdülókor idillikus vágyait tükrözik, a nehezen megfogalmazható igényeket, motivációkat a stabil, kiegyensúlyozott életre. Jelzik a posztadoleszcencia ambivalens, nehezen kontrollálható viszonyait.

A munkavállalás, karrier, az anyagi javak birtoklása kis mértékben, de megelőzi a házasság és gyermekvállalás tervét. Ez a jelenség általánosan érvényes a fiatalokra, ahogy az Ifjúság 2004 kutatás is jelzi. Nem mernek, nincs igényük, nincs lehetőségük. E tendencia további elemzésre ad lehetőséget, vajon miért fontosabb a munka, mint a gyermekvállalás. Hallgatóink többsége egyértelmúen a bizonytalan anyagi viszonyokat, megélhetési lehetôségeket mondják, de valószínúleg a kitolódott serdülókor, az identitás kialakításának elhúzódó folyamata is eredményezheti ezt. Valamint a fogyasztói társadalom által közvetített értékek, az anyagi javak megszerzésének fontossága, a közösségi normák átrendezôdése is befolyásolja a választások 


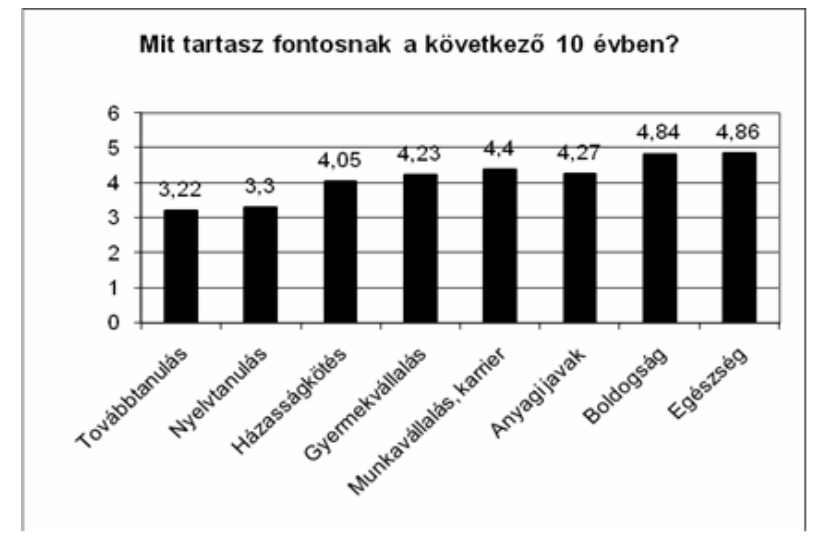

3. ábra. Mit tartasz fontosnak a következő 10 évben?

sorrendjét. A tanulás, mint cél végzôseinknél nem preferált tényező. Tapasztalatainkat igazolja, hogy nem érték, szükséges dolog csupán a diploma megszerzéséhez.

A jövố legfontosabb célkitűzése, az egészség megơrzése számukra. Azonban az eredmények arra utalnak, hogy nem sok erôfeszítést tesznek ennek érdekében. Az elméleti tudás, az egészség védésének fontossága megvan, de nem sokat tesznek érte. A válaszaik is tükrözik ezt. Az ötfokú skálán adott átlagos értékeik átlagosak, alacsonyak (4. ábra). A többség preferálja a szürövizsgálatokon való részvételt. Ez

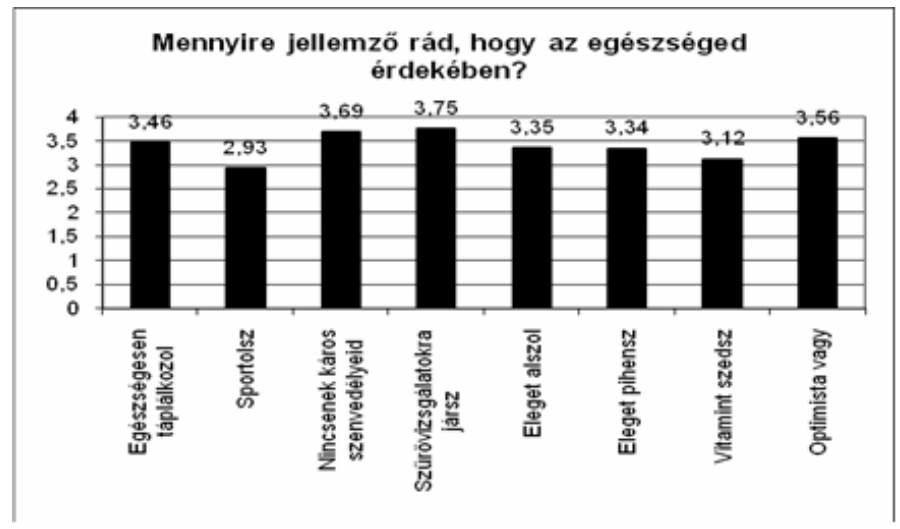

4. ábra. Mennyire jellemző rád, hogy egészséged érdekében?

bizakodásra adna okot, de tudjuk, hogy a gyakorlati tárgyakon való részvétel miatt ez kötelezô számukra. A hallgatók legkevésbé sportolnak az egészségükért, pedig 
fontos védőfaktor, a stresszkezeléshez, valamint a különféle betegségek megelőzéséhez is szükséges. Az egészségügyben tanulóként pedig tudják, hogy a sportolás, a megfelelő stresszkezelés, a megfelelő mennyiségú és minôségú alvás, pihenés, az egészséges táplálkozás is nagy szerepet játszik az egészségmegörzésben és a betegség nélkül töltött évek minél nagyobb számában. Ennek tudatosítása, tudatos alkalmazása szintén olyan tényező, amire fel kel hívni figyelmüket.

Tendencia, hogy a felsőfokú végzettségú édesapák gyermekei látogatják leginkább a szưrôvizsgálatokat. Az otthonról hozott normák, szabályok befolyásolhatják ezt. Magasabban kvalifikált családok esetében az egészség fenntartása érdekében fontos érték a prevenció.

Vizsgálatunkban az egyetemet végzett édesanyák gyermekeire a legkevésbé jellemzố tulajdonság az optimizmus. Érdekes eredmény. Nőként karriert építeni nehezebb, aminek következménye lehet az emocionális instabilitás, aminek következtében az anyák nem tudnak egy optimista, magabiztos mintát nyújtani gyermekeiknek.

A nôknél kevésbé gyakori a sport, mint a férfi hallgatóknál. Sajnos nem „divat” sportolni, a lányok kevésbé látják át ennek fontosságát, valamint nem igénylik a mozgást.

A szabadidô eltöltésére a következô tendenciák érvényesek. A legdominánsabb válasz a beszélgetés volt, ami nem meglepó, hisz a segítő szakmáknál jelentkezô stresszt a beszélgetés nagyszerúen oldja. Ezen szakmáknál nagyon fontos a kikapcsolódás, a regenerálódás, a stresszkezelés hangsúlyozása, hisz a személyiség nagy hangsúlyt kap a munkavégzés során, aminek fejlesztésére tudatosan figyelni kell. Azonban más védőfaktorok alkalmazása is fontos. A családdal töltött idó és a párjukkal töltött idó is jellemzô. A zenehallgatás, a barátokkal töltött idô, az internetezés, a szabadban eltöltött idô, a tévézés, illetve filmnézés is kedvelt szabadidôs tevékenység. Az olvasás is jelen van a listán, de nem jellemzó a fiatalokra. Sajnos a kötelezố tantárgyak esetében is találkozunk ezzel. A vallás meg sem jelenik a válaszaikban. A szórakozás, táncolás nem jellemzô módja a kikapcsolódásnak a megkérdezetteknél. Újra megjelent, hogy a szabadidejükben történô sportolás sem jellemzô a hallgatókra, ami eléggé elkeserítő, ha azt nézzük, hogy Egészségügyi Karra járó fiatalokról beszélünk, akik még a sport jelentőségével is tisztában vannak és fontos számukra az egészség. Pedig a lehetôség a sportra, a tartalmas közösségi programokra adott a kar hallgatói számára. A szabadidő eltöltésének kreatív módjai nem elfogadottak a fiatalok körében, nem alkalmazzák ezeket. Pedig az önkifejezés, aktív részvétel ezekben a programokban erősíti az önbizalmat, önismeretet, hatékony segítséget jelent a társas közegben való alkalmazkodáshoz, valamint a segítô érzelmi stabilitását segítik elô, feltöltődést biztosító tevékenységek.

\section{Összegzés}

Vizsgálatunk során megpróbáltuk feltérképezni azokat a befolyásoló tényezóket, melyek meghatározhatják a leendô segítő hivatást vállaló szakemberek jövôjét. 
Összességében elmondható, hogy nem könnyư manapság fiatalnak lenni. A munkavállalás a gazdasági helyzet miatt nehezebbé vált, de végzôseink optimistának túnnek. Az előzetes elvárásaink, miszerint nem népszerú körükben a választott szakmájuk, nem érzik azt hivatásuknak, nem szeretnének elhelyezkedni abban, nem igazolódott. A legtöbb megkérdezett szeretne segítóként dolgozni, és vállalja annak kihívásait, annak ellenére, hogy tisztában vannak a szakmák társadalmi, erkölcsi, anyagi bizonytalanságaival.

A házasságkötési és gyermekvállalási terveket vizsgálva kiderült, hogy a házasságot fontosnak tartják a megkérdezettek, bár nem tartják a gyermekvállalás feltételének. Az a tendencia is nyomon követhető, hogy kevesebb gyermeket szeretnének, mint elődeik, és azt is késôbbi időpontban, mint a korábbi generáció. A házasságkötést és a gyermekvállalást is reálisan látják a fiatalok, tehát felelôsségteljesen szeretnének dönteni.

Az egészség megôrzése fontos tényezô számukra, ám paradox módon nem sokat tesznek érte. A segító szakmákban dolgozók számára elengedhetetlen a megfeleló stressz és konfliktuskezelés, a megfelelő önismeret, a személyiség kompetenciaérzésének átélése. Sajnos kevés figyelmet, energiát fordítanak erre.

Úgy gondolom sokkal motiváltabbá, tudatosabbá kell tenniük hallgatóinkat a jövôjük tervezésében. Több segítséget kell nyújtanunk számukra, hogy a mindennapi szakmai munkából származó problémákat kezelni tudják, hogy jobban érezzék magukat, kreatív, másokon valóban segítô szakemberek lehessenek. A munkavállalás, a párválasztás, családalapítás nehézségeivel tisztában kell lenniük, hiszen ezek megoldása vezethet igazán stabil identitáshoz. A tudatos, önmegvalósító ember pedig hatékony, kompetens segítôvé válhat. Ha el tudjuk érni, hogy bízzanak jövôjükben, bízzanak önmagukban, hogy a nehéz társadalmi, egzisztenciális, érzelmi valóságban helyt tudnak állni, képesek a közösség aktív tagjaivá válni, akkor valóban eredményes volt munkánk. Ennek megvalósítása közös felelősség. Megfelelő életvitellel és pozitív hozzáállással könnyebben teljesíthetik a felnôtté válás során rájuk váró feladatokat és a folyamat végére kreatív, magabiztos, stabil énnel rendelkezô felnôtté válhatnak. Olyan felnôttekké, aki megfelelő kompetenciával, énhatékonysággal képesek a szakmai elvárásoknak megfelelni. Olyan segítókké, akik számára lehetôséget biztosíthatunk az elméleti és gyakorlati képzés során, hogy ismerjék meg személyiségüket, megfelelő differenciáltsággal, ismeretekkel fejlesszék azt, és tudják alkalmazni a mindennapi segítô munka során.

\section{Irodalomjegyzék}

1. Arnett, J. J. (2000) Emerging Adulthood. A Theory of Development From the Late Teens Through the Twenties. American Psychologist, Vol. 55. No. 5, 469-480.

2. Arnett, J., J. (2007): Emerging Adulthood: What Is It, and What Is It Good For? Child Development Perspectives, Volume 1, Issue 2, pages 68-73, December 2007. 
3. Atkinson R. L. (2003): A pszichológiai fejlődés. In: Atkinson R. L., Atkinson R. C., Smith E. E., Bem D. J., Nolen-Hoeksema S. (szerk.): Pszichológia. Osiris Kiadó, Budapest. 71-104.

4. Bognár Virág. (2007): Elsô elszakadás a szülői háztól: a felnôtté válás kezdete. In: Somlai P. (szerk.): Új ifjúság. Napvilág Kiadó, Budapest. 45-80.

5. Bohleber W. (1999.):Psychoanalyze, Adoleszenz und das Problem der IdentitätPsyche, LIII-6-Juni-507-526.

6. Kabai Imre. (2007): A magyar egyetemisták és főiskolások életútja, élettervei 2004-ben. In: Somlai P. (szerk.): Új ifjúság. Napvilág Kiadó, Budapest. 111-153. 7. Kalo J., Pándy M., Popper P., Ranschburg J. (2007): Felcserélt szerepek Nagyszerú nók, gyönyörú férfiak?. Saxum Kiadó, Budapest.

8. Kamarás Ferenc. (2005): Családalapítás és gyermekvállalás Európában. Kérdések és kérdőjelek. In: Nagy I., Pongrácz T. , Tóth I. GY. (szerk.): Szerepváltozások. Jelentés a nôk és a férfiak helyzetéról 2005. TÁRKI ICSSZÉM, Budapest. 87-101. 9. Keniston (1970):Youth: As a stage of life. American Scholar, 39.

10. Lukács F. (2007) Egyetemisták és fôiskolások pályaválasztási bizonytalansága és a pályakonzultáció In Puskás-Vajda Zs. (szerk.) Felsôoktatásban tanuló fiatalok problémái, útkeresése, pályafejlődése a 21. század kezdetén Magyarországon. FETA Konyvek 2., Budapest.

11. Magyari Judit (2009): A családi narratívák és a jövootól való szorongás összefüggései pályakezdô fiataloknál In: Egy igazolt praxis felé Újabb eredmények a pszichológia és a felsôoktatási tanácsadás hazai kutatásaiból szer: Puskás-Vajda Zs.- Lisznyai S. FETA Könyvek 4. Budapest.

12. Margitics Ferenc (2006): A szubklinikus depressziós tünetegyüttes háttértényezőinek vizsgálata fơiskolai hallgatóknál Doktori értekezés, Debreceni Egyetem. 13. Mitchell, B. A. (2007) The Boomerang Age: Transitions to Adulthood in Families. Transaction Publishers, U.S.A. Murdock, N. L., \& Gore.

14. Pikó Bettina(2005): Vallásosság, egészség és káros szenvedélyek az ifjúság körében In: Ifjúság, káros szenvedélyek és egészség a modern társadalomban szerk: Pikó Bettina Nemzeti Drogmegelôzési Intézet, Harmattan, Budapest.

15. Pongrácz Tiborné, Spéder Zsolt. (2003): Élettársi kapcsolat és házasság - hasonlóságok és különbségek az ezredfordulón. Szociológiai Szemle, 4. 55-75.

16. Puskás-Vajda Zsuzsa - Susánszky Éva (2010): Az egyesületi tagság háttér jellemzői fiatal felnôtteknél In: Életszakaszok határán Közösségi és egyéni tanulási feladatok szer: Puskás-Vajda Zs.- Lisznyai S. FETA Könyvek 5. Budapest.

17. Ranschburg Jenô. (2007b): Szülők könyve, a fogantatástól az iskolakezdésig. Saxum Kiadó Bt., Budapest.

18. Somlai Péter. (2007): A posztadoleszcensek kora. Bevezetés. In: Somlai P. (szerk.): Új ifjúság. Napvilág Kiadó, Budapest. 9-43.

19. Spéder Zsolt. (2006): A gyermekvállalás idôzítése az életútban, különös tekintettel a szülő nô iskolai végzettségére és párkapcsolati státuszára. Demográfia, 2-3. 113-149.

20. Spéder Zsolt. (2005): Az élettársi kapcsolat térhódítása Magyarországon és 
néhány szempont a demográfiai átalakulás értelmezéséhez. Demográfia, 2-3. 187217.

21. Tóth Olga. (2007): Fiatalok párkapcsolatai történelmi háttérrel. In: Somlai P. (szerk.): Új ifjúság. Napvilág Kiadó, Budapest. 81-109.

22. Utasi Ágnes. (2004): Feláldozott kapcsolatok - A magyar szingli. MTA Politikai Tudományok Intézete, Budapest.

23. Vikár György: (1999): Az ifjúkor válságai. Animula, Budapest.

24. Xiao, H., Andes, N. (1999): Sources of parental Values. Journal of Human Values, 5, 157-167.

Oroszné Pál Zsuzsanna: főiskolai tanársegéd

Debreceni Egyetem, Egészségügyi Kar, Nyíregyháza, 4400, Sóstói út 2-4. 